\title{
Solar Powered T Source Inverter Fed Permananent Magnet Brush Less DC Motor Drive System
}

\author{
Nubla Fathima K.A. ${ }^{1}$, Reena R. Rajan ${ }^{2}$ \\ PG Student [Power Electronics and Drives], Dept. of EEE, NCERC, Thrissur, Kerala, India ${ }^{1}$ \\ Assistant Professor, Dept. of EEE, NCERC, Thrissur, Kerala, India ${ }^{1}$
}

\begin{abstract}
This paper deals with the performance analysis of solar powered $\mathrm{T}$ source inverter fed Permanent Magnet Brushless DC Motor Drive. Here Z source inverter is replaced by T source inverter. Disadvantages of driving a BLDC with ZSI is overcome by replacing it with TSI. The operating principle of TSI is explained here. The performance analysis of BLDC driven by TSI is carried out. A simulation of three phase T source inverter fed BLDC is done using MATLAB/Simulink.
\end{abstract}

KEYWORDS: T source inverter, BLDC motor.

\section{I.INTRODUCTION}

Renewable energy source is becoming inevitable now a day. Increasing energy demands push us to discover new ways. Recently renewable energy power supplied into the utility grid has been paid much attention due to increase in fossil fuel prices, environmental pollution and energy demand boom. Among various renewable energy resources such as solar, wind, tidal, geothermal, biomass, etc., the solar photo voltaic system being more attractive and promising green resource because of its abundant availability in universe, safe resource, cost free and eco-friendly. Make use of this available energy is one of the ideas to overcome the energy crisis. PV sources are used in many applications like battery charging, water pumping system, home power supply, swimming pool heating system etc. There is a growing trend among the pump manufacture to use PMBLDC for higher efficiency and low maintenance. Solar powered BLDC motor is considered here.

The use of $\mathrm{Z}$ source inverter (ZSI) to extract maximum power will overcome the problems due to conventional two stage converters. The conventional power inverters such as voltage source inverter (VSI) and current source inverter (CSI) have its own limitations. In which VSI require additional stage for boosting the input voltage and dead time is required, in case of CSI extra stage is required to buck the input voltage and overlap time is required to stay away from the open circuit. This additional stage leads to lower efficiency and complex control.

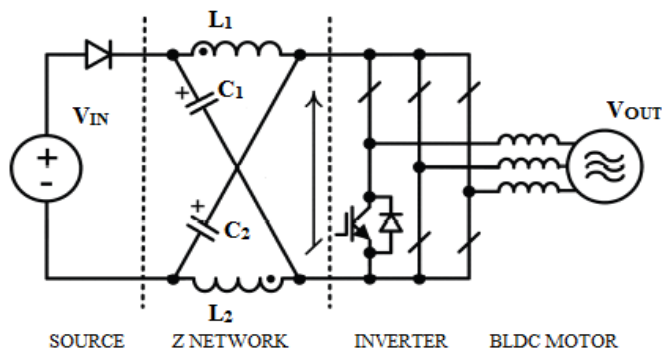

Fig.1. Equivalent Circuit of ZSI Fed BLDCM

When we use ZSI in some applications the efficiency seems to be lower than the conventional converters. Common point of grounding of primary source, LC network and inverter bridge is so important to reduce the EMI disturbance. 


\title{
International Journal of Advanced Research in Electrical, Electronics and Instrumentation Engineering
}

\author{
(An ISO 3297: 2007 Certified Organization)
}

Vol. 4, Issue 7, July 2015

This is not possible in case of ZSI. ZSI is sensitive to parasitic inductances of galvanic connections and capacitors of LC impedance network. These inductances causes significant over voltages during switches commutation and results in over sizing of switches used in ZSI. For boost ratio greater than 2, ZSI faces some stability problem. So to overcome these drawbacks of ZSI we go for T source inverter. It provides an extended possibility of manipulation of inverter output voltage, by changing the transformer turn ratio other than one. Figure 1. Shows the equivalent circuit of ZSI fed BLDC motor.

\section{LITERATURE SURVEY}

Traditional inverters like voltage source inverter (VSI) and current source inverter (CSI) are replaced by Z source inverter (ZSI). The problems faced by using traditional inverters are solved by ZSI. Still there were some problems. ZSI lack common point of grounding of source, LC network and inverter. This grounding is important in reducing EMI. For higher boost ratio greater than 2, ZSI faces stability problem. To overcome these $\mathrm{T}$ source inverter is introduced.

\section{III.T SOURCE NETWORK}

In TSI the number of passive elements is less, only a HF transformer and a capacitor is required. The T-network is used instead of the LC-network for boosting the output voltage by inserting shoot through states in the PWM. It allows shoot-through states of the inverter legs during boost operation as well open circuits of inverter legs during normal (buck) operation. Above features ensure robustness of the inverter during incorrect turn on of transistors or during appearance of external EMI disturbances.

$\mathrm{T}$ network is the three terminal equivalent of basic four terminal LC network $(\mathrm{Z})$. Three terminal form is more convenient and it has the advantage of common input and output terminal. Symmetry theory of impedance network states that; equivalent passive network be obtained if a four terminal network is divided through its axis of symmetry and if the ideal transformer with ratio 1:1, connecting the two halves is short circuited. By this theory we can convert $\mathrm{Z}$ network to a T network.

TSI fed BLDC motor has four sections. First one is the source; it can be any dc source. For example fuel cell or car battery, PV panel etc. Second section includes the T network. It consists of two inductors of same parameters and a capacitor. Inductors can be a mutually coupled inductor or a high frequency transformer. Third is the inverter section. It is a normal three phase inverter. One end connected to T network and the other end connected to the motor. Last section is the load section. Brush Less DC motor is used as the load.

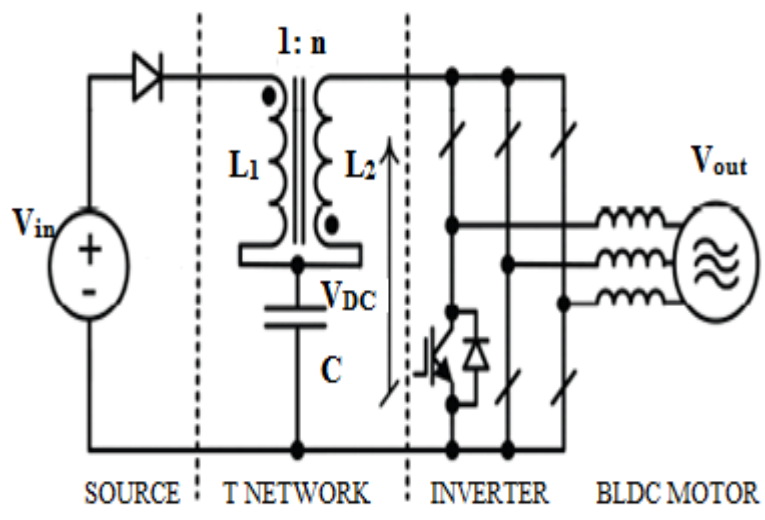

Fig.2. Equivalent Circuit of TSI Fed BLDCM 


\section{International Journal of Advanced Research in Electrical, Electronics and Instrumentation Engineering}

(An ISO 3297: 2007 Certified Organization)

Vol. 4, Issue 7, July 2015

\section{WORKING PRINCIPLE}

The DC voltage is fed as input to the impedance network of TSI which helps to achieve voltage buck boost properties. Solar panels are used to provide the DC voltage. Then the output of the impedance network is applied to the inverter main circuit. TSI has two modes of operation; non-shoot through mode and shoot through mode. Figure 2; illustrate the equivalent circuit of TSI.

Non-Shoot Through Mode: In this mode the inverter bridge operates in one of traditional active states, thus acting as a current source when viewed from $\mathrm{T}$ - source circuit. Capacitors get charged during this mode. Voltage is obtained across the load. The diode conducts and carries current difference between the inductor current and input DC current. Both the inductors have an identical current because of coupled inductors. Figure 3, shows the equivalent circuit of TSI in Non-Shoot through mode.

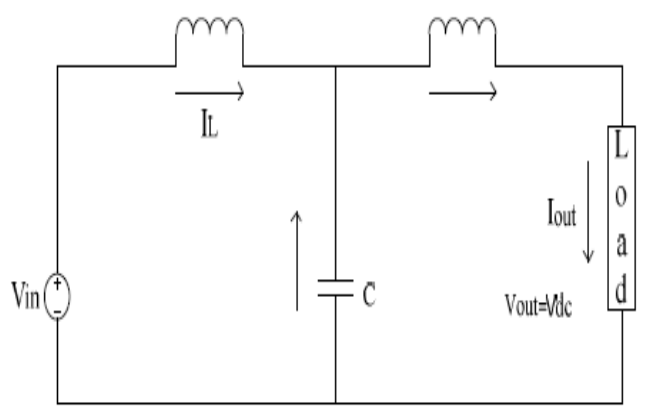

Fig.3. Equivalent Circuit of TSI In Non Shoot Through Mode

Shoot Through Mode: This shoot through zero state is prohibited in traditional voltage source inverter. It can be obtained in three different ways such as shoot through via any one phase leg or combination of two phase leg or shoot through via three phase legs. During this mode, diode gets reverse biased; and separate DC link from AC line. Capacitor gets discharged and charges the inductors. This will help in boosting the output voltage. Figure 4, shows the equivalent circuit of TSI in shoot through mode.

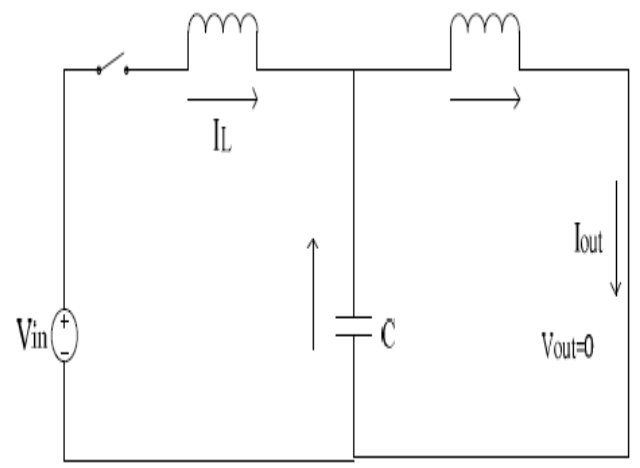

Fig.4. Equivalent Circuit of TSI In Shoot Through Mode 


\section{International Journal of Advanced Research in Electrical, Electronics and Instrumentation Engineering}

(An ISO 3297: 2007 Certified Organization)

Vol. 4, Issue 7, July 2015

\section{IV.SIMULATION RESULT AND DISCUSSION}

There are number of simulation software available and here the simulink part of the MATLAB is employed. Simulation of both ZSI and TSI fed BLDCM is performed here. Figure 5, shows simulation diagram of TSI fed BLDCM.

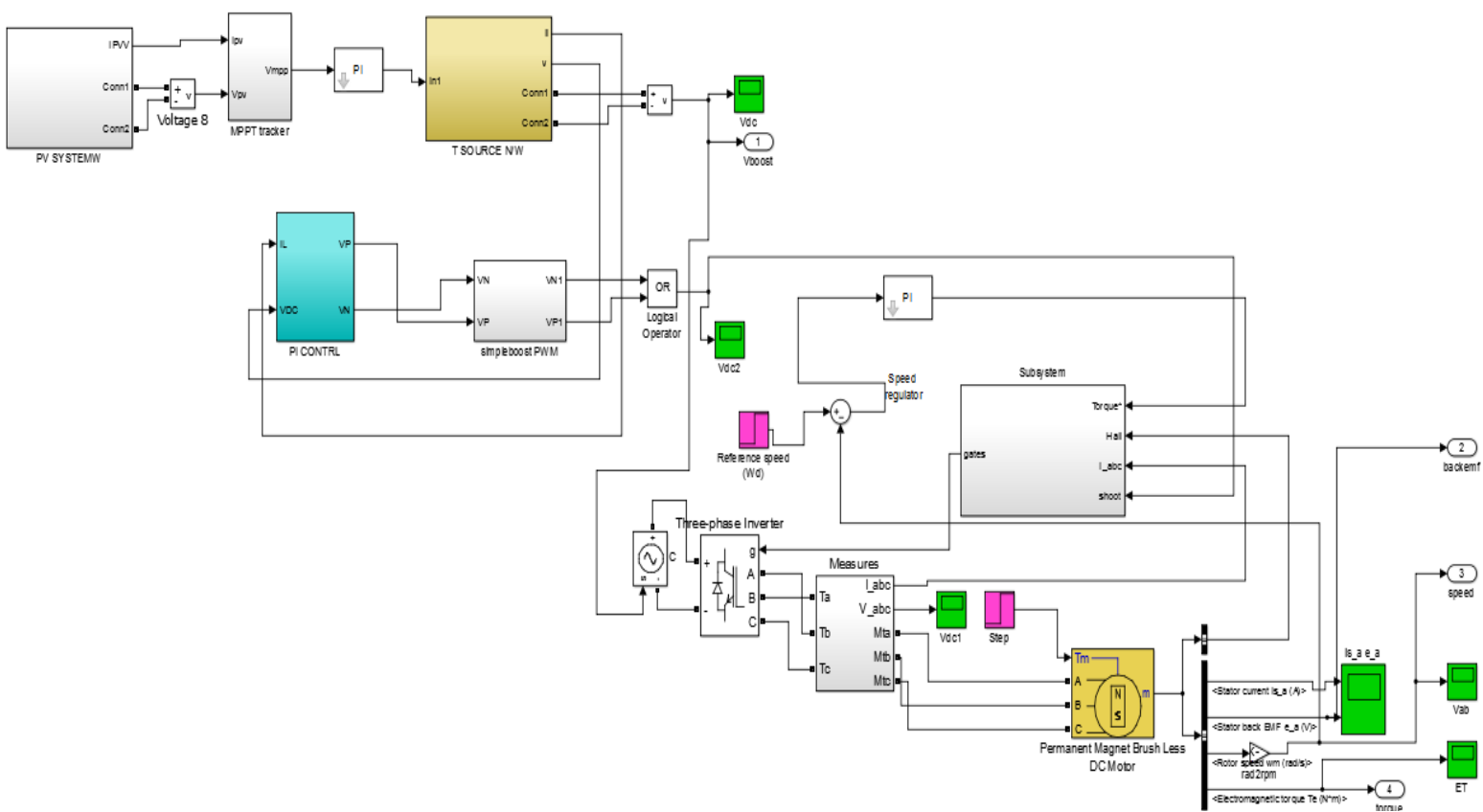

Fig.5. Simulation Diagram of TSI Fed BLDCM

A prototype of the ZSI and TSI fed BLDCM was simulated through MATLAB. Only the $\mathrm{Z}$ and $\mathrm{T}$ network was changed in the simulation diagram. Control scheme is maintained same in both cases. The simulation diagram of T network is shown in figure 6.

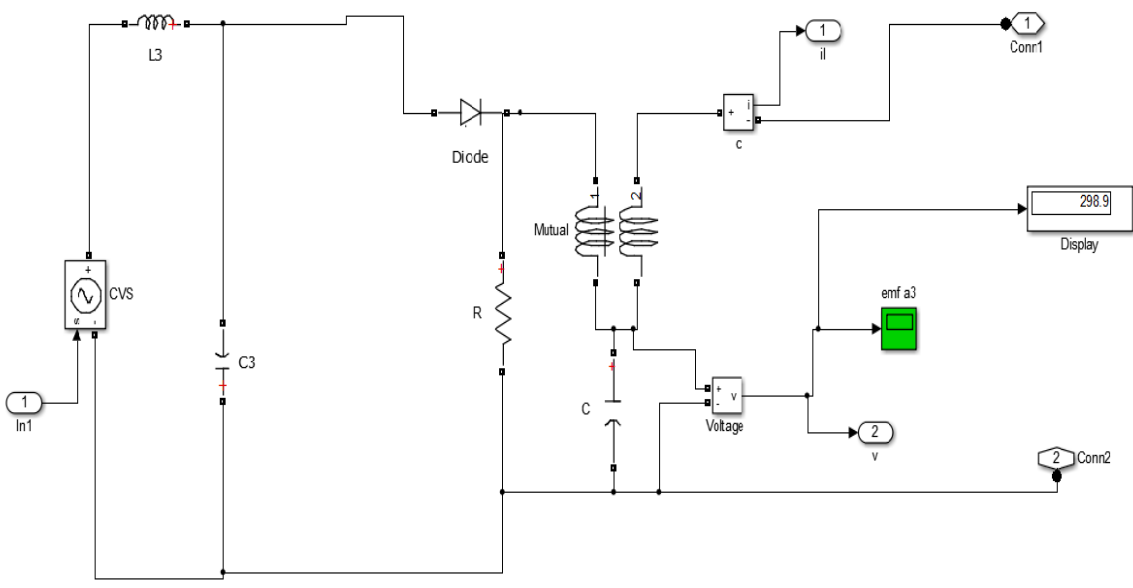

Fig.6. Simulation Diagram of T Network

Design parameters of $\mathrm{Z}$ and $\mathrm{T}$ network are given in Table I. Two inductors and two capacitors of ZSI have same values. Capacitor value of TSI should be approximately equal to twice the value of capacitor used in ZSI. Coupled inductors are used in TSI. 


\section{International Journal of Advanced Research in Electrical,} Electronics and Instrumentation Engineering

(An ISO 3297: 2007 Certified Organization)

Vol. 4, Issue 7, July 2015

Table I. Design Specifications of ZSI and TSI

\begin{tabular}{|c|c|c|c|c|c|}
\hline \multicolumn{3}{|c|}{ ZSI } & \multicolumn{3}{|c|}{ TSI } \\
\hline & PARAMETER & VALUE & & PARAMETER & VALUE \\
\hline L1 & Inductor 1 & $0.016 \mathrm{mH}$ & $\mathbf{R}_{1}$ & \multirow{2}{*}{$\begin{array}{l}\text { Winding } 1 \text { Self } \\
\text { Impedance }\end{array}$} & 1.1ohm \\
\hline $\mathbf{L} 2$ & Inductor 2 & $0.016 \mathrm{mH}$ & $\mathbf{L}_{1}$ & & $2 \mathrm{mH}$ \\
\hline C1 & Capacitor 1 & $500 \mu \mathrm{F}$ & $\mathbf{R}_{2}$ & \multirow{2}{*}{$\begin{array}{l}\text { Winding } 2 \text { Self } \\
\text { Impedance }\end{array}$} & $1.10 h m$ \\
\hline $\mathrm{C} 2$ & Capacitor 2 & $500 \mu \mathrm{F}$ & $\mathbf{L}_{2}$ & & $4 \mathrm{mH}$ \\
\hline- & - & - & $\mathbf{R}_{\mathrm{m}}$ & \multirow{2}{*}{$\begin{array}{l}\text { Mutual } \\
\text { Impedance }\end{array}$} & 1ohm \\
\hline - & - & - & $\mathbf{L}_{\mathrm{m}}$ & & $1 \mathrm{mH}$ \\
\hline & & & C & Capacitor & $950 \mu \mathrm{F}$ \\
\hline
\end{tabular}

Torque, speed and back emf with simulation time characteristic of TSI fed BLDC motor is shown in figure 7. The boosted voltage of ZSI and TSI is shown in figure 8, and 9 respectively.

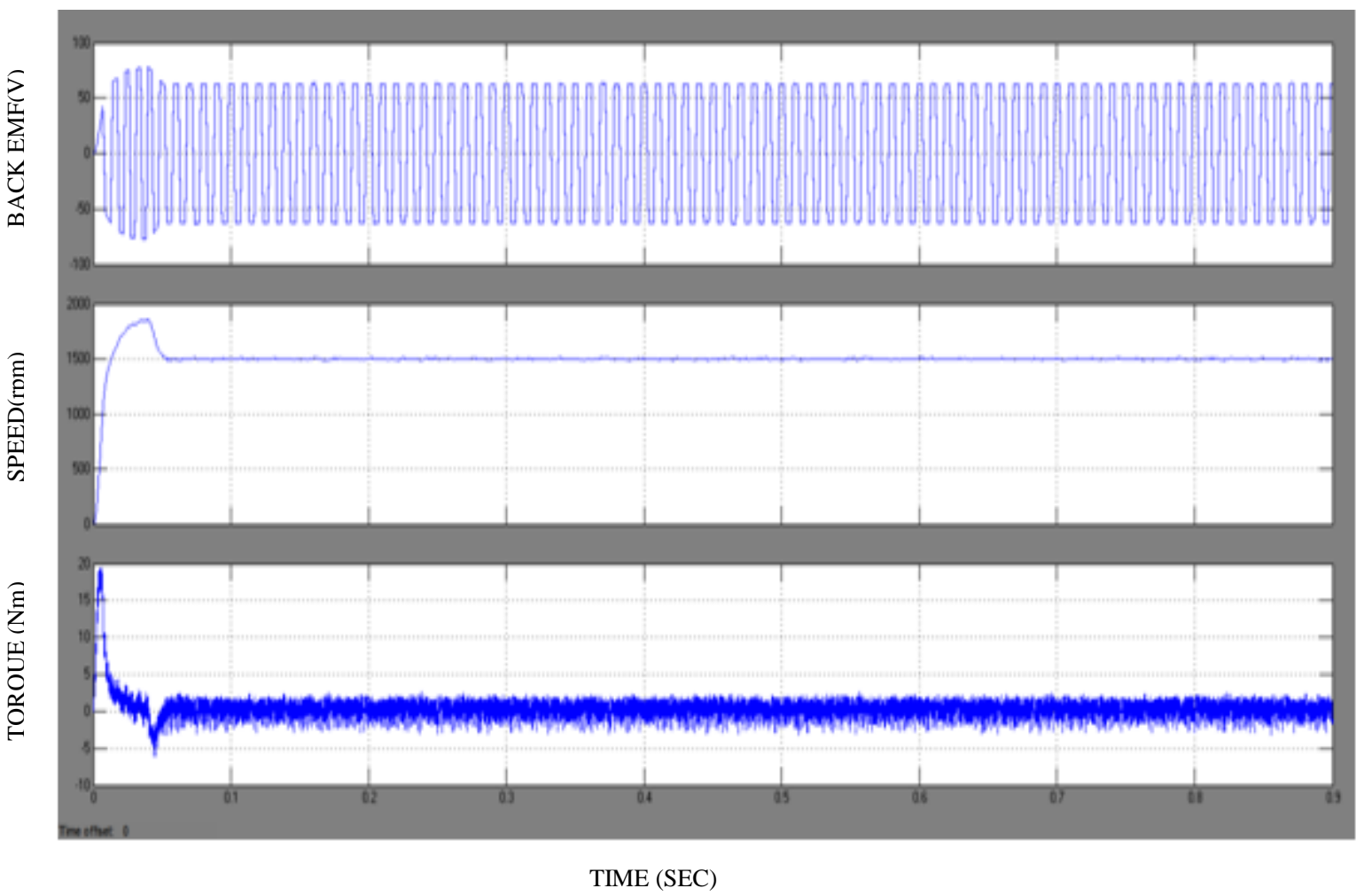

Fig 7. Torque, Speed And Back EMF With Time Characteristics of TSI Fed BLDCM 


\section{International Journal of Advanced Research in Electrical, Electronics and Instrumentation Engineering}

\section{(An ISO 3297: 2007 Certified Organization)}

\section{Vol. 4, Issue 7, July 2015}

Initially there is a rise in electromagnetic torque. This is because the initial back emf is very small, so torque is proportional to current. This results in high magnitude of torque in the beginning. Trapezoidal back emf is obtained. Initially speed increases to a value above rated speed and then it settles to rated speed.

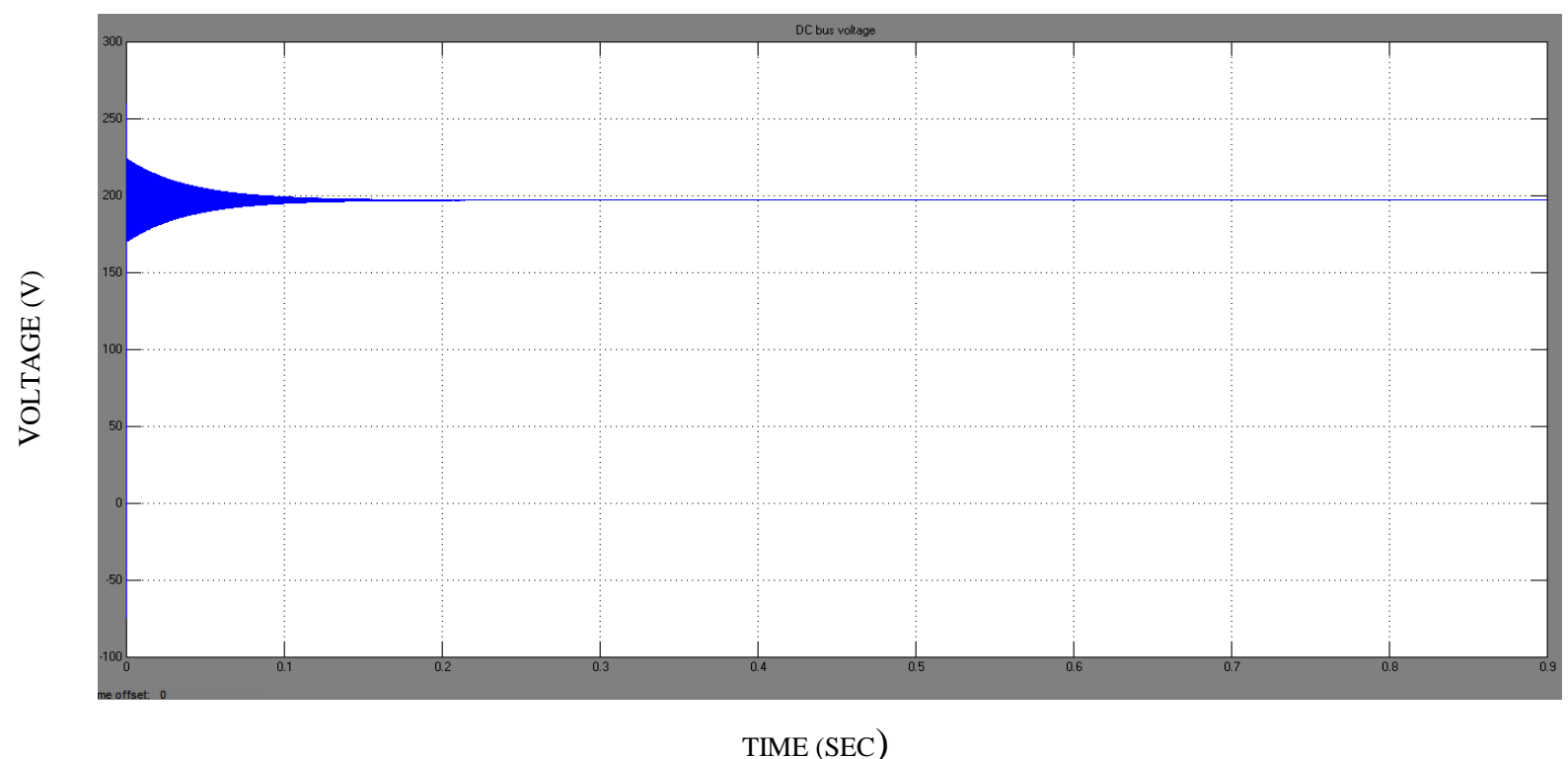

Fig 8. Boost voltage of ZSI

An input of $36 \mathrm{~V}$ is give to both ZSI and TSI. The boosted voltage of ZSI is $200 \mathrm{~V}$ and that of TSI is $300 \mathrm{~V}$. There is a delay in reaching the boosted voltage in case of ZSI. The boosted voltage is obtained without much delay in case of TSI

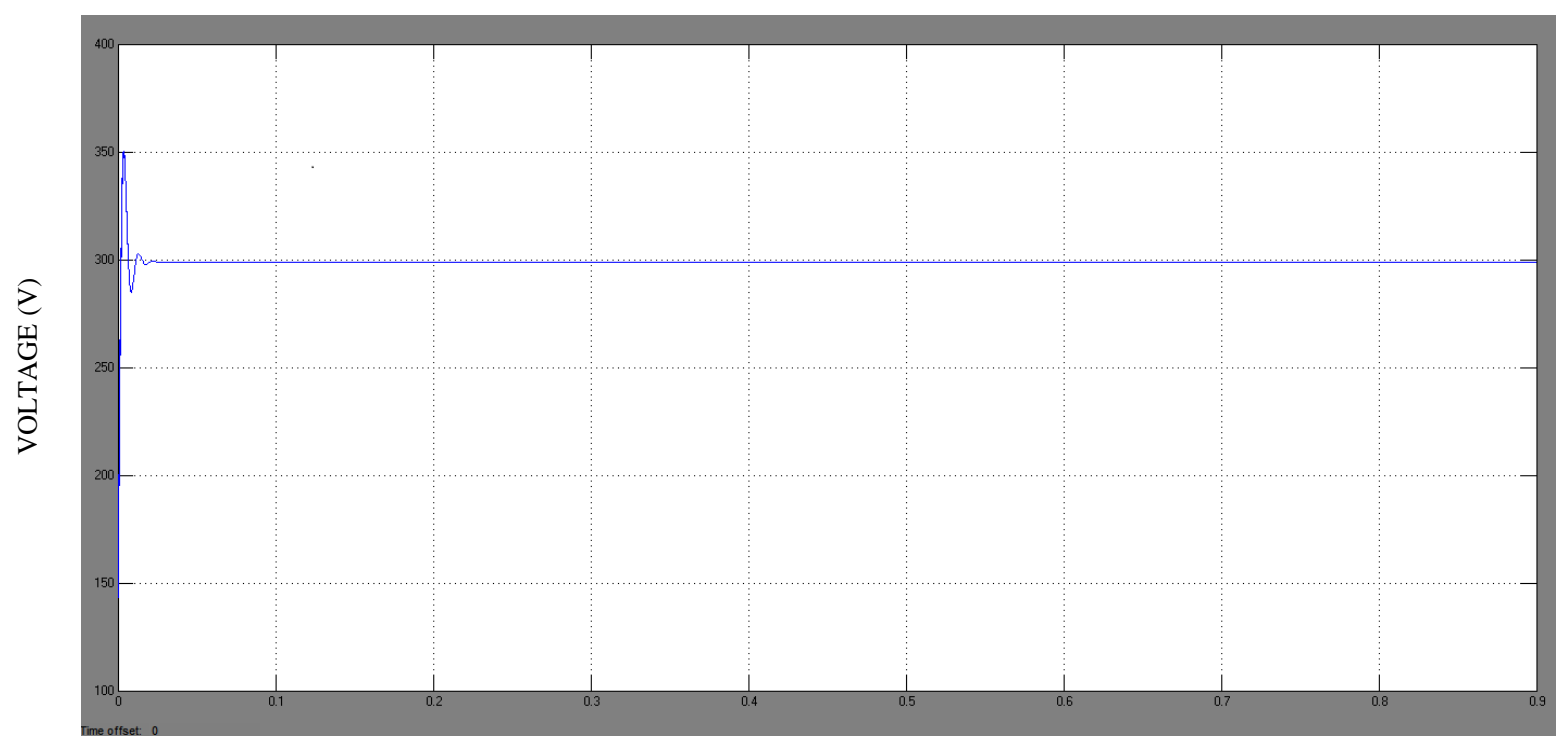

TIME (SEC)

Fig. 9 Boost voltage of ZSI 


\title{
International Journal of Advanced Research in Electrical, Electronics and Instrumentation Engineering
}

\author{
(An ISO 3297: 2007 Certified Organization)
}

Vol. 4, Issue 7, July 2015

\section{V.CONCLUSION}

Thus TSI gives a higher boost voltage when compared to ZSI. The performance of BLDCM is better with TSI. TSI provide a common point of grounding of primary source, passive network and the inverter bridge. It has less passive components. By changing the turn ratio of the high frequency transformer, which is used instead of two inductors; the output voltage of the T network can be changed.

\section{REFERENCES}

[1] F.Z.Peng, "Z Source Inverter," IEEE Transaction on Industry Application, vol.39, pp. 504-510, march- april 2003

[2] F.Z. Peng, “Z Sourse Inverter For Motor Driver”, IEEE Transactions on PowerEelectronics, vol.20 No.4, july 2005.

[3] R.Strezelecki, "New type T source Inverter," IEEE Conference on Compatibility and Power Electronic. pp 191 - 195, may 2009.

[4] M. Adamowicz, N. strezelecka, T source inverter," Przegląd Elektrotechniczny (Electrical Review), pp.233-238, october 2009.

[5] S. Panwar, R.P.Saini, " Development and simulation of solar photovoltaic model using matlab/simulation and its parameter extraction," International Conference on Computing and Control Engineering, April 2012. 